\title{
PROPOSING A DIGITAL INFORMATION SYSTEM FOR THE MANAGEMENT AND CONSERVATION OF THE QHAPAQ ÑN - ANDEAN ROAD SYSTEM
}

\author{
Duperré, Gustavo Norberto ${ }^{a}$ \\ a,Dirección General de Cultura y Educación. Calle 13 e/ 56 y 57, 1900. La Plata, Argentina - \\ ${ }^{a}$ Facultad de Historia, Geografía y Turismo. Universidad del Salvador. Viamonte 2213, Buenos Aires. Argentina, C1056ABI - \\ gustavo.duperre@usal.edu.ar
}

KEY WORDS: Qhapaq Ñan, Andean Road System, Cultural Heritage, Conservation, Management, Integrated Digital Model, Digital Humanities, Digital Tools

\begin{abstract}
:
The ancient network of roads in the Andean region is one of the most important works of infrastructure in South America. The extensive territory where the main exchanges between their communities were locally performed is previous to the expansion of the Inca Empire. In the year 2014, the region was included on the World Heritage List by the United Nations Educational, Scientific and Cultural Organization.

This communication network is the Qhapaq Nan, Andean Road System. The Incas planned their route in the diverse landscape of the Andes to promote social and economic ties among the Andean communities. The routes originated in the central square of Cusco, creating cross-connections in a wide geographical area. The Tawantinsuyu depended on this sole route to link very distant production and worship centers.

The Qhapaq Nan was the result of a political project. Even nowadays, it continues to articulate the development of cultural traditions in the Andean region. The present contribution analyzes its transcendental importance as a Cultural Heritage and the singularity of its nomination by the UNESCO, as for the first time six countries are sharing common objectives towards guaranteeing its protection. Furthermore, this research explores the sense of timing in Latin American countries and the implicit challenges in the implementation of the new information technologies for the dissemination of information on Main Andean Road and for its conservation.

Although many of the countries have already incorporated the necessary digital tools in this matter, we conclude that there is a need to implement an Integrated Digital Model for the coordinated management in the countries that form the region.
\end{abstract}

\section{INTRODUCTION}

The Cultural Heritage management is offering new challenges, and this matter is occupying the agenda of the majority of the institutional actors involved, especially as regards the growing need to implement digital tools that will allow to improve management, conservation and dissemination of information of those sites recognized by the UNESCO World Heritage Convention (UNESCO, 2014). This implementation process closely involves creative industries (UNESCO Santiago Office, 2016) as an essential support for discussion of ideas and information flows, favoring the exchange of new technologies at a global scale.

In those regions where countries should be managing the recently included Sites into the World Heritage List in an integrated manner, heritage digitalization is regarded as a valuable opportunity, but any obstacle regarding the shared tasks of implementing management actions needs to be vanquished. One very recent precedent in South America refers to the inclusion of the transboundary Qhapaq Ñan - Vial Andean System, which is unique because of its specific geographical features and historical background, since this was the first time that a territory shared by six countries in the region was designated by UNESCO to be a World Heritage Site (UNESCO, 2014).

General objective: The study of the Main Andean Road, contemplating its anthropological and historical values as a Cultural Itinerary by UNESCO.
Specific objectives: a) Expose the degree of merit, usefulness and interest of contemporary management policies applied to the Andean Road System and the potential of various digital tools that will favor direct and/or indirectly the dissemination of the infomation on the Cultural Heritage in Latin American countries. b) Propose the Application of an Alternative Digital Model, to be incorporated to the exisiting digital tools and be used in the development of shared actions towards the protection of the Main Andean Road.

The methodology of research is exploratory and is based on the collection and analysis of bibliographic and online information. It attempts to generate trends of study in a broader framework of future possibilities.

\section{QHAPAQ ÑAN - ANDEAN ROAD SYSTEM}

The road network that communicated the Andean territory presents a vast ecological diversity, in addition to the countless places linked to their ancestral cosmovision such as the summits of the hills and water shafts. (Bouysse-Cassagne, Harris, Platt and Cereceda, 1987).

The Andean region is a vast geographic and historic space ranging from contemporary Colombia through several countries: Venezuela, Ecuador, Peru, Bolivia and Argentina, up to the South of the continent in the fertile central region of Chile (González Díaz, Aguilar Hidalgo and Garrido Escobar, 2015). Hence its importance in historical terms, in addition to the territorial variable that acts as a catalyst for cultural integration between the urban settlements along its path. 
The Qhapaq Ñan, Andean Road System, is an ancient symbol of approach between human beings, territories and cultures, it is the expression of important processes of exchange of knowledge and cultural traditions, goods, and communication between peoples and territories (UNESCO, 2014). [Fig. 1]

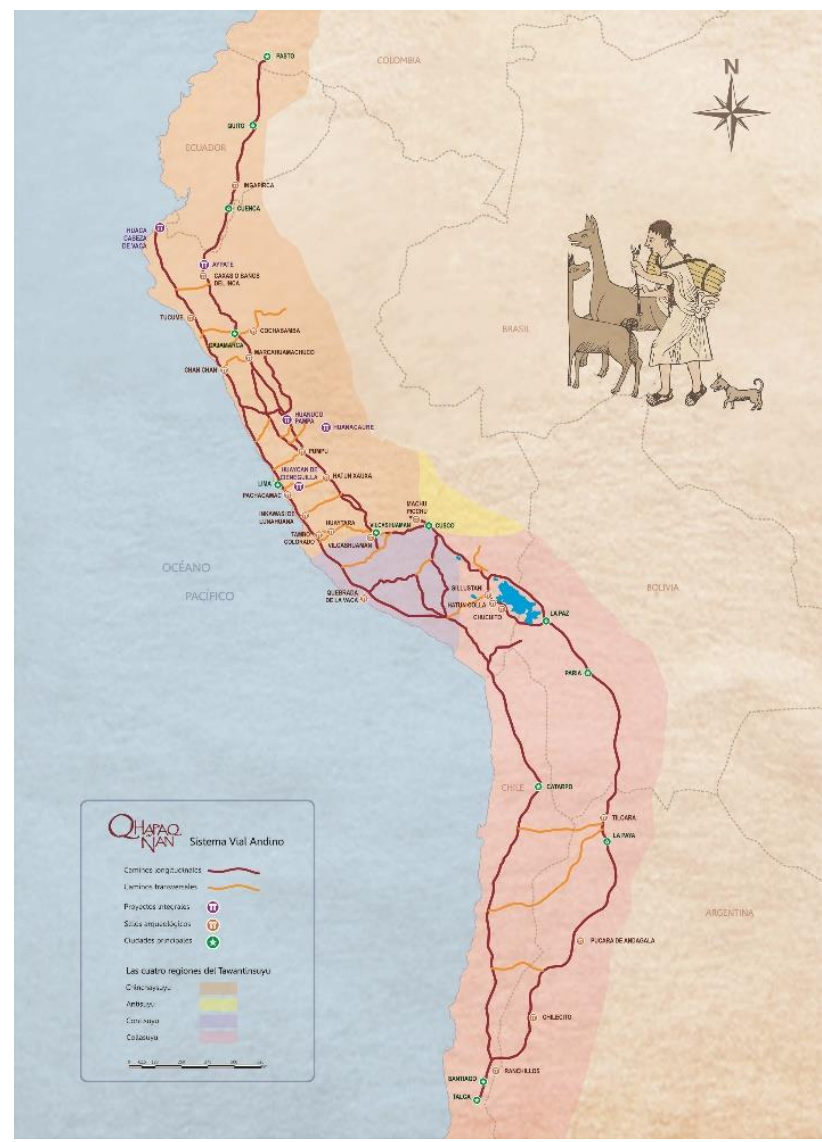

Figure 1. Map of Qhapaq Ñan - Andean Road System. Detail of roads, Projects, Archaeological Sites, Cities and Regions of the Tawantinsuyu. (C) Project Qhapaq Nan - Sede Nacional, 2017. Ministerio de Cultura, Gobierno de Perú.

\subsection{Historical background}

The Instituto Nacional de Antropología y Pensamiento Latinoamericano in Argentina has established a series of clarifications: The system of roads of the Andes was one of the most important solutions created by man to take advantage of the different Andean ecosystems and to link the settlements located in its various regions, promoting the interaction in social, economic, cultural, technological, political and ideological values along the Tawantinsuyu known since the $16 \mathrm{TH}$ century as Qhapaq Nan (Great Road).

This roadline network was more than $30,000 \mathrm{~km}$ long and connected several production, administrative and ceremonial centers built through more than 2,000 years of pre-inca Andean culture. Its importance lies not only in its magnitude but also in the remarkable engineering that was implemented in this rugged geography, as well as in the ability to organize and unify the immense Andean territory, and the effective management of the associated populations, each of them with its own traditions which continue nowadays (Instituto National de Antropología y Pensamiento Latinoamericano, 2015). On a separate issue, the Academic Day: Protection, conservation and management of the Qhapaq Nan, heritage, organized by the UNESCO Chair on Cultural Toursim (Untref - Aamnba); describes the Qhapaq Ñan as the oldest road system in Argentina and South America, that in Argentina only covers seven provinces, which is the reason why to gather knowledge and experiences focussed on its protection, conservation and management [...] have been the main purposes of this day (UNESCO Untref - Aamnba, 2015).

\subsection{UNESCO Declaration}

In a joint political effort, convergence was carried out of the historical traits and the participation of South American countries that currently form this vast region, which in preHispanic times belonged to the Inca Empire. The result of this process has granted these territories a new cultural dimension and enhancement: The Qhapaq Nan or Andean Road System was included on the World Heritage List of UNESCO, as a transboundary Cultural Route, on June 21, 2014, during the $38^{\circ}$ meeting of the World Heritage Committee of the United Nations Organization for Education, Science and Culture, gathered in Doha, Qatar. The Declaration [...] means the international recognition of this Engineering Masterpiece [...] its people, their ancient traditions, usage patterns, values and principles (Ministerio de Cultura, Gobierno de Perú, 2016).

\subsection{Towards an integrated project management}

Argentina, Bolivia, Chile, Colombia, Ecuador and Peru share a common Cultural Heritage of outstanding universal value (OUV): Main Andean Road - Qhapaq Nan. During the past three years, UNESCO World Heritage Centre has assisted these countries in the development of a pioneer project through preparing one single nomination for the inclusion of the Qhapaq Ñan in the World Heritage List. This process involved an original and innovative regional cooperation framework (UNESCO World Heritage Centre, 2016).

The regional imbalances in the countries involved make this nomination a real challenge, especially with regards to the conservation of the different sections, urban communities, religious centers and historical sites spreading throughout the length and width of the Andean Corridor. In 2017, and for two years, Argentina will assume the Presidency pro tempore of the Inca Trail Committee. This means that the country will face a greater challenge, as is to unify the internal management and afterwards allocate/coordinate tasks with the rest of the Andean countries (Telam. Agencia Nacional de Noticias, 2016).

Concerns on the conservation of the sections that are located under the jurisdiction of the different provinces is cause of reflection, particularly with regards to potential conflict of interests in terms of economic priorities:

Some warning signs around the challenges $[\ldots]$ and opportunities associated with UNESCO nomination have a previous history in equally fragile environments, such as the Quebrada de Humahuaca, World Heritage (2003). But these signs may also be a call for attention to other landscapes worthy of being protected [...] seriously threatened by real estate investment pressures, the absence of laws regarding land management [...] the lack of opportunities for sustainable economic development (and) the disposals of the land (Cátedra UNESCO de Turismo Cultural Untref-Aamnba, Fundación Grupo El Abra, Salta, 2016).

\section{A DIGITAL INFORMATION SYSTEM}

The steady advancement in technology and the increase of the deterioration factors together with regional and global political and cultural controversies bring to light the urgent need of actions to ensure the conservation of this network in an effort to 
to be handed down to posterity. The need to integrate different disciplines puts us before innovation models in the field of Humanities and their implementation in the digital world.

\subsection{Digital Humanities}

Digital Humanities is a term that includes this new interdisciplinary field, which seeks to understand the impact and relationship of information technologies in the work of Humanities researchers. This term is also known as Digital Resources for Humanities [...] This new field has become increasingly important in the international academic field and offers exciting new possibilities for the development in research and teaching in Humanities (Russell, 2011). In this sense, El Colegio de Mexico (Colmex) and the Universidad Nacional Autónoma de Mexico (UNAM) stand out as important examples; especially as regards the possibility of using the Network of Digital Humanities (RedHD) to support communication between digital humanists from different regions. A digital humanist works with a large number of specialists such as computer technicians, engineers, scientists, and philosophers, among others (Porcayo, 2016). In addition, the news agency of the Consejo Nacional de Ciencia y Tecnología (Conacyt) of Mexico is carrying out a sustained process in the incorporation of digital technologies for the dissemination of the Cultural Heritage. From an interdisciplinary perspective, the implementation of new technologies puts us before new scenarios in the field of heritage conservation.

\subsection{Contemporary demands: Qhapaq Nan conservation}

The Andean Road System has an outstanding universal value. Its incorporation to the World Heritage List results from a series of requirements of integrity and authenticity that guide actions towards its protection. Within national contexts, management systems have been developed in cooperation with the local communities and include debates for the perpetuation of the living traditions associated with the Qhapaq Ñan. [Fig.2]

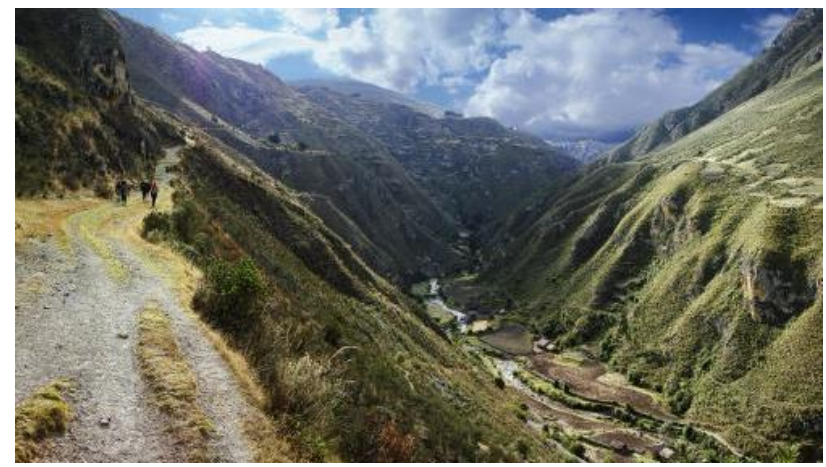

Figure 2. Tramo Huanuco Pampa - Huamachuco, Path trace in the valley of the river Taparaco, Llata, Huamalíes, Huánuco. Qhapaq Ñan Sede Nacional, 2017. Ministerio de Cultura, Gobierno de Perú.

Several local communities explicitly expressed their interest in tourism activities intended to be managed and carried out at a community level (UNESCO, World Heritage Centre, 2017).

To sustain conservation actions in all those sections of the road system that have been deteriorated and have even disappeared translates into a sense of opportunity for the development of sustainable tourism activities and integration through the folklore that bonds communities associated with the place. These singularities introduce the discussion on the implementation of an Integrated Digital Model, which shall transfer the values of a living Cultural Heritage.

\subsection{Digital tools in Latin American Countries}

The Andean Road System demands international cooperation to make this proposal be one of the big projects in documentation and conservation in the World Heritage. In this context, we take as a reference the Ministerio de Cultura de Peru, which Portal uses a multimedia platform that allows access to information in different languages about different sections of the Qhapac Nan. Geocultura, for example, features an interactive map of the region where virtual-flight tours of Drones can be done using a selection of videos in its geographic reference localization that includes the Qhapaq Nan. [Fig. 3]

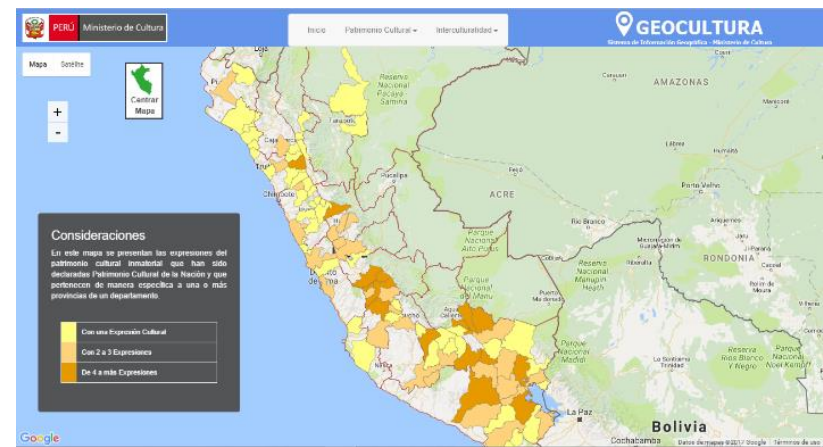

Figure 3. Interactive map: Flight of drones and virtual tours. Peru. Sistema de Información Geográfica-Geocultura. Google. Image: Screen capture, 2017. Google Maps and Google Earth. Ministerio de Cultura, Gobierno de Perú.

It also has zoning maps where expressions of the Intangible Cultural Heritage of Peru are shown. It includes architectural records and sections of the Andean Road System in the navigation menu: Qhapaq Ñan Perú Sede Nacional. [Fig. 4]

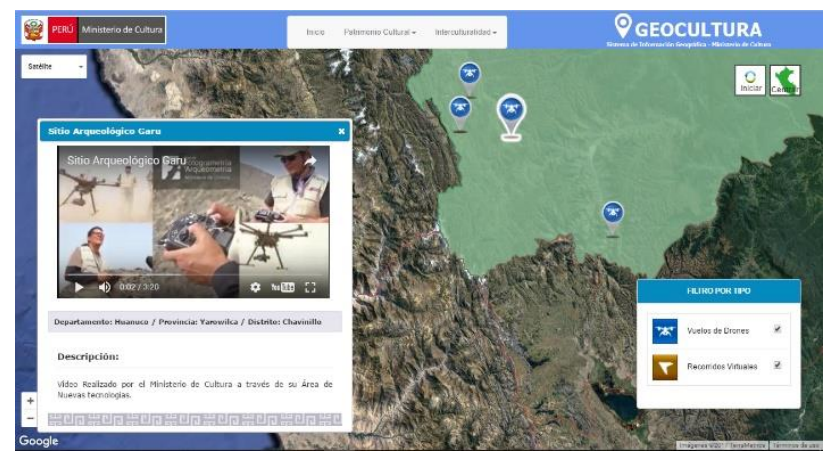

Figure 4. Expressions of the Intangible Cultural Heritage of Peru. (C) Qhapaq Nan Sede Nacional. Image: Screen capture, 2017. Ministerio de Cultura, Gobierno de Perú.

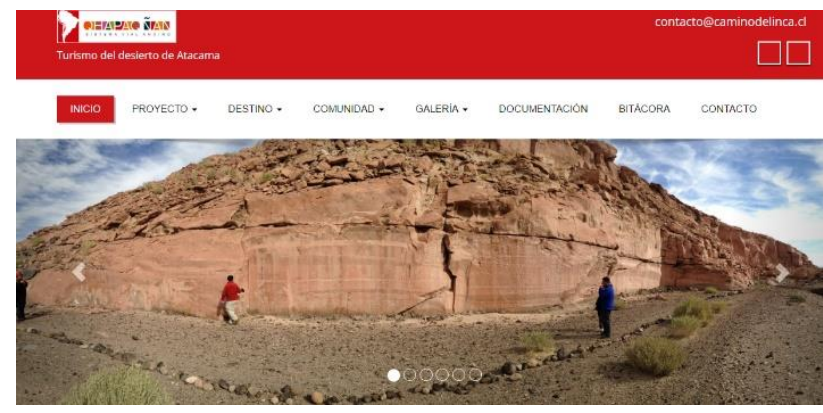

Figure 5. Routes of the Qhapaq Ñan, Chile. @ Q Qhapaq Ñan Sistema Vial Andino. Image: Screen capture, 2017. Proyecto Qhapaq Ñan Desierto de Atacama, Chile 
The Geographic Database of the IGN (Instituto Geográfico Nacional) in Argentina facilitates the knowledge of the geological structures, curved levels, GPS of Protected Areas of Provinces that form part of the Qhapaq Nan. The GIS and the layers of analysis provide a great variety of useful data. [Fig. $6-$ 7]

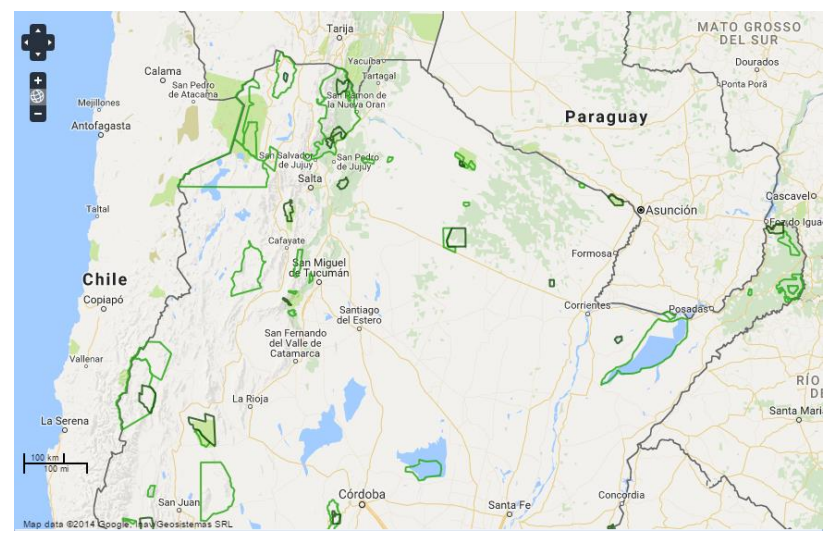

Figure 6. Protected Areas in the Provinces of Argentina that integrate the Andean Road System. (C) Instituto Geográfico Nacional, 2016. Base de Datos Geográfica. Visor SIG.

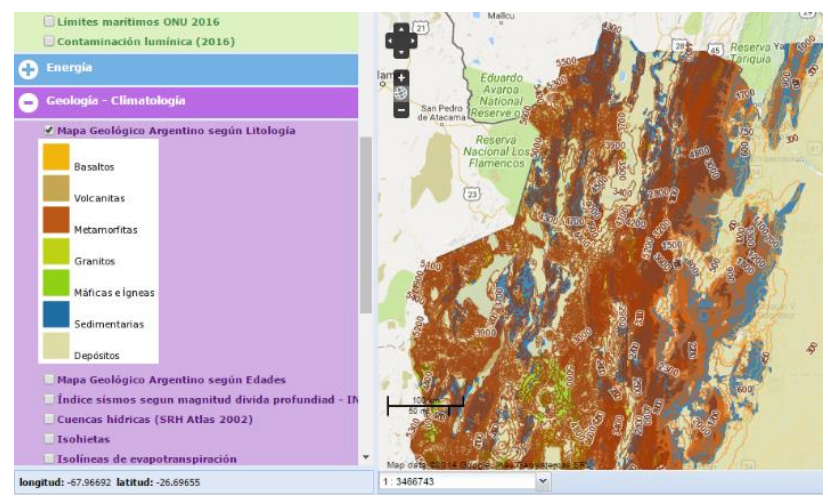

Figure 7. Protected Areas in the Provinces of Argentina that integrate the Andean Road System. (C) Instituto Geográfico Nacional, 2016. Base de Datos Geográfica. Visor SIG.

\subsection{An alternative Digital Technologies Network}

Based on the abovementioned, we will propose an alternative resource that can be integrated to the existing digital tools. [Table 8]

\begin{tabular}{|c|c|c|}
\hline Components and Actions 3.4 & \multicolumn{2}{|c|}{ Programming Software } \\
\hline Research & 3.4 .1 & Data \\
Compilation & 3.4 .1 & Resources \\
Interpretation & 3.4 .2 & Publishing \\
Text editing & 3.4 .2 & App \\
Linkers & 3.4 .3 & Design \\
Debugger & 3.4 .3 & Control \\
\hline & & Educational software \\
Integrated Development & 3.4 .4 & (Assembly ) \\
Environment (IDE) & & Interactive digital \\
Qhapaq Nan & 3.4 .5 & platform \\
Virtual Museum & & \\
\hline
\end{tabular}

3.4.1 Research: Landscape study. Sections of the Main Road System. Google Earth [Fig. 9], SIG. Geocultura (Perú).

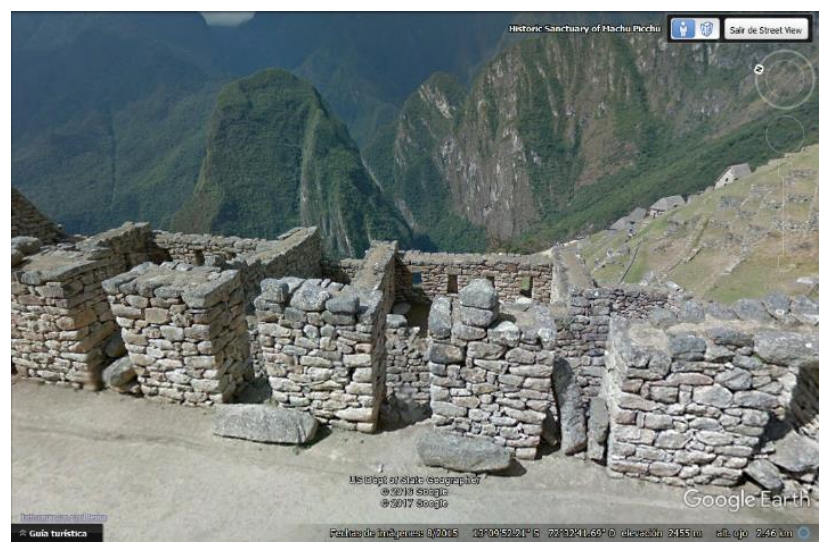

Figure 9. Historic Sanctuary of Machu Picchu. Peru. (C) US Dept. of State Geographer. GOOGLE. Image: Screen capture, 2017. Google Earth.

3.4.2 Digital tools: For example Arches is an open-source, geospatially-enabled software platform for cultural heritage inventory and management, developed jointly by the Getty Conservation Institute and World Monuments Fund. (Arches Project, 2017). [Fig. $10-11$ ]
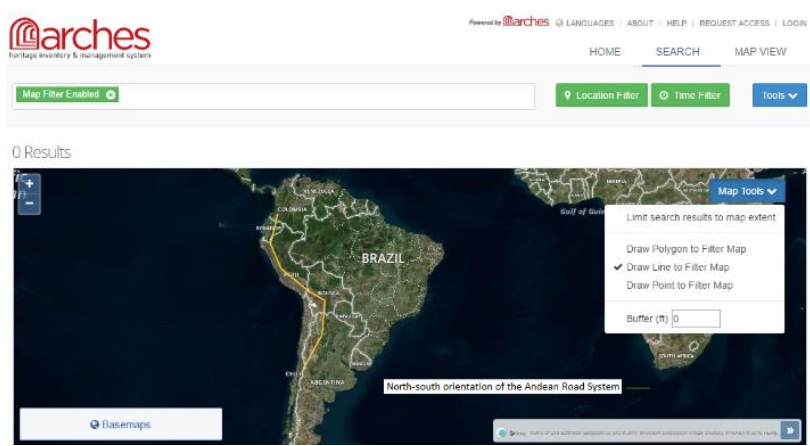

Figure 10. North-south orientation of the Andean Road System (C) Arches Project. Image: Screen capture, 2017 (Adapted: Multiple Locations, UNESCO, World Heritage Centre).
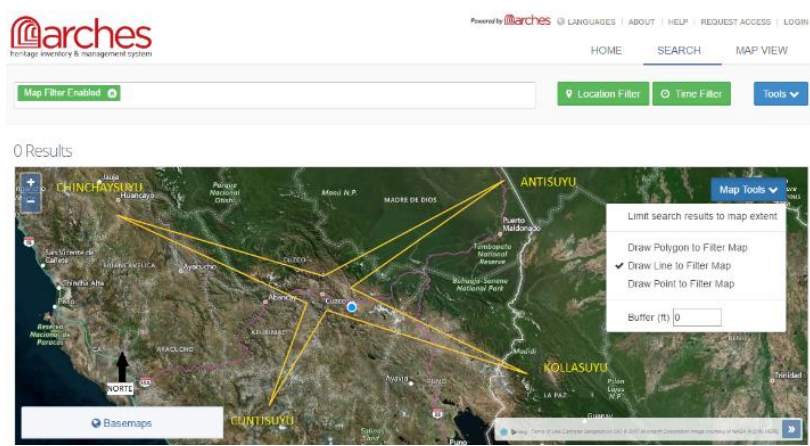

Figure 11. Radial system of zeq'e (lines) of Cusco (C) Arches Project. Image: Screen capture, 2017 (Adapted de Bauer in D’Altroy, 2003, Los Incas. p. 195. Ariel Pueblos, Barcelona).

3.4.3 Editing: Digitization and programming.

Table 8. Diagram adapted: Technology and Computer Science. Integration: Alternative Network of Digital Technologies [Point 3.4]. 
3.4.4 Assembly: Construction of narrative discourses on the landscape, archaeological Sites and the associated Communities of the Andean Road System. Relationship of the tangible and intangible Heritage with the geographic space and historical context. [Fig. 12] Ethical awareness and identification of values respect to the conservation of the Cultural Heritage of Humanity. [Fig. 13 - 14]

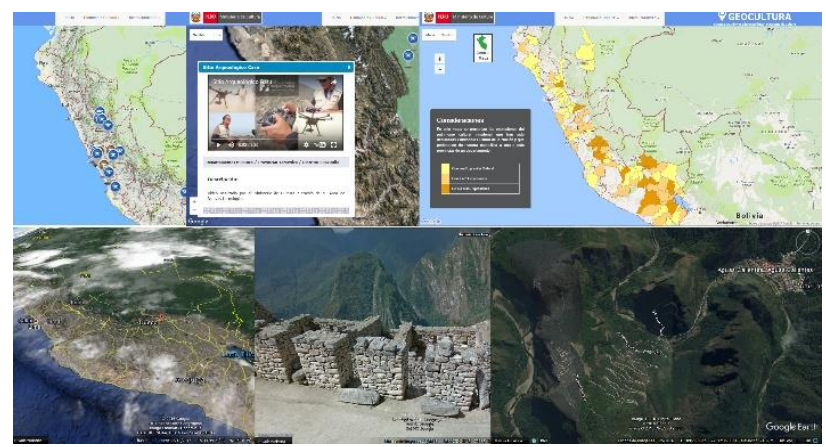

Figure 12. Geographic situation of the Andean Road System and Drones flight and Virtual Tour in Peru. @ Sistema de Información GeográficaGeocultura; Google Maps and Google Earth and Arches Project. Images: Screen capture, 2017.

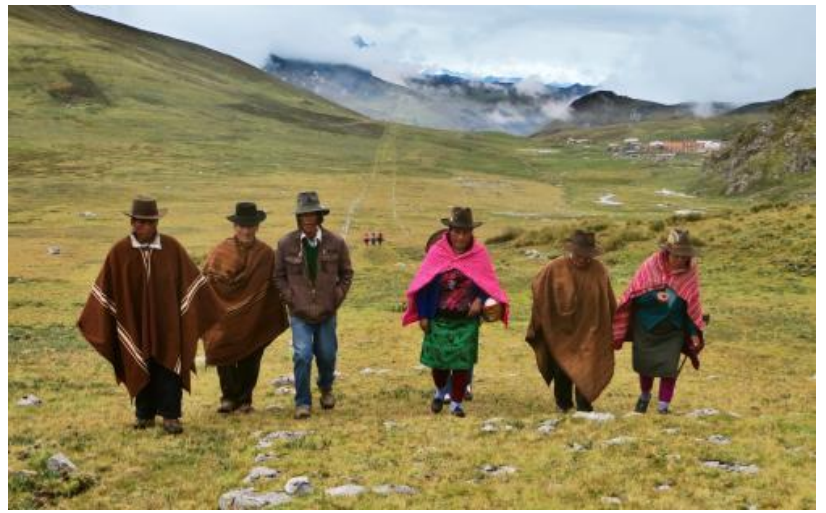

Figure 13. Section Huanuco Pampa - Huamachuco, inhabitants of Huamanin traveled Inca Trail, San Marcos, Huari, Ancash. @ Project Qhapaq Ñan - Sede Nacional, 2017. Ministerio de Cultura, Gobierno de Perú.

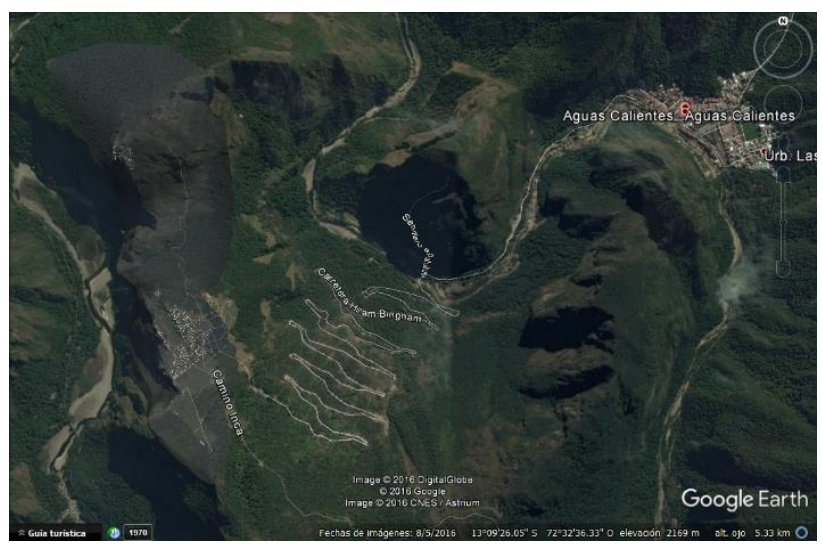

Figure 14. Geographical situation of Machu Picchu and its connection with the City of Aguas Calientes and the Inca Trail. () US Dept. of State Geographer. Google. Image: Screen capture, 2017. Google Earth.
3.4.5 Virtual Museum Main Andean Road: Interactive digital platform (Tangible and Intangible Heritage of Qhapaq Nan).

Table number 8 presents the components and actions (Alternative Network of digital technologies - item 3.4) integrated in the programming of educational software (Virtual Museum of Qhapaq Nan). The items 3.4.1 - 3.4.5 relate to the contemporary digital tools, with practical activities for the conservation and protection of the Andean Road System.

The incorporation of Digital Humanities [Fig. 15], Portals of the Ministry of Culture of Peru and Chile, Arches Project, Google Map and Google Earth; and GIS implementation in Argentina, are essential for the development of the proposed Digital Information System.

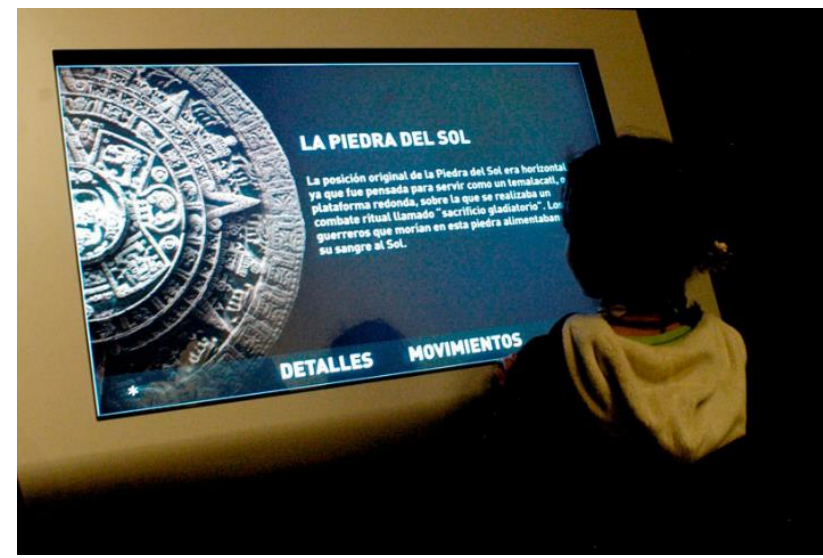

Figure 15 . Digital technologies for the dissemination of cultural Heritage. Details and movements: Piedra del Sol. (C) Conacyt Agencia Informativa, 2017. México.

The multimedia resources (platforms of YouTube and Vimeo) are necessary in the contextualisation of the historicalarchaeological variables of Qhapaq Ñan. [Fig. 16]
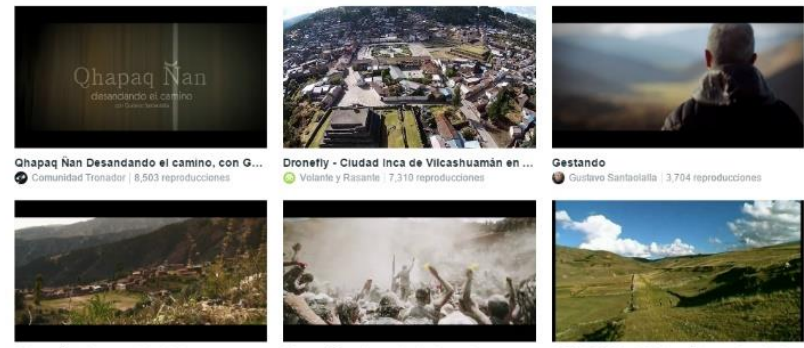

Onapaq Nan, La voz de los Andes
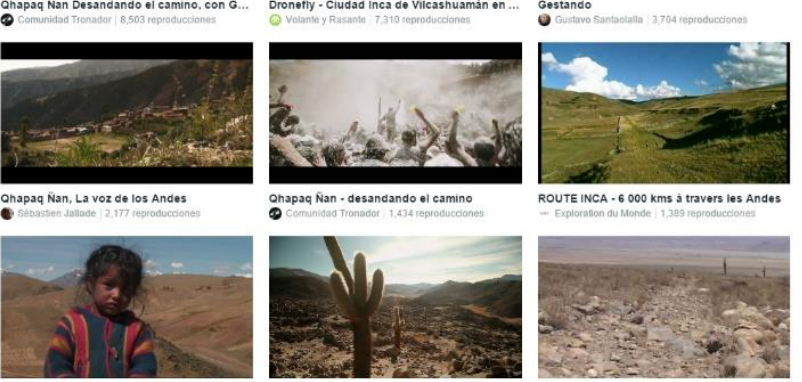

ROUTE INCA - $6000 \mathrm{kms}$ a travers les Andes

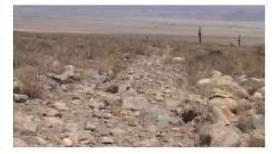

Figure 16.Search results: Qhapaq Nan on the Vimeo Social Network. () Vimeo. Image: Screen capture, 2017.

The initiative of a Digital Information System for the design of a Virtual Museum for the Andean Road increases the value of the Cultural Heritage of South America and the integration of conservation policies for the six countries that share the protection of Qhapaq Nan. 
An interesting case study related to this project is the Silk Roads Cultural Heritage: The Silk Roads serial transnational World Heritage nomination initiative is one of them. For the first phase of the Silk Roads serial transnational World Heritage nomination, two priority cultural corridors in Central Asia and one in China were selected. To carry out this task, two projects will be working in conjunction, the Japanese Funds-in-Trust UNESCO project dealing with the support for documentation standards and procedures of the Silk Roads Serial and transnational World Heritage Nomination in Central Asia, and the Silk Roads Cultural Heritage Resources Information System (CHRIS) project. The Silk Roads CHRIS project is an UNESCO WHC initiative funded by the Belgian Federal Science Policy Office (BELSPO) and executed by a Belgian consortium headed by the Raymond Lemaire International Centre for Conservation at the K.U.Leuven supporting the Silk Roads serial transnational World Heritage nomination of the five Central Asian countries, namely, the Republics of Kazakhstan, Kyrgyzstan, Tajikistan, Turkmenistan and Uzbekistan (Vileikis, Santana Quintero, Van Balen, Dumont and Tigny, 2011).

Considering the management of The Silk Roads, the design of an Application of an Integrated Model for the Qhapaq Nan is at an exploratory stage. Although Latin American institutions have incorporated new technologies to the study and conservation of the Cultural Heritage, the integration of actions in countries that share common objectives respect to the preservation of the Andean Road System is essential.

\section{LESSONS LEARNED}

Qhapaq Nan is an ancient testimony of the ancestors of the Inca Empire that transcends the usual boundaries of other cultural itineraries, taking as a reference the World Heritage List. The management of the engineering and planning constitutes one of its greatest achievements, taking into account the strong contrast of the landscape of the territory in South America. [Fig. 17]

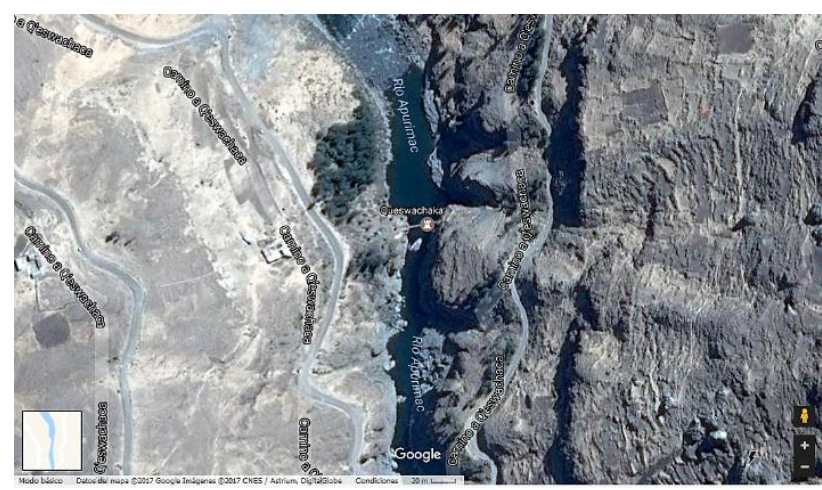

Figure 17. View of the Inca Bridge of Qeswachaca - Peru. @ US Dept. of State Geographer. GOOGLE. Image: Screen capture, 2017. Google Earth.

In the XXI century, the Andean Road System continues to articulate the communication between local towns. These features not only translate into a sense of potential opportunities for the sustainable development of tourism and cultural activities, but also lead to many challenges for its protection according to the Declaration of the UNESCO World Heritage Site. [Fig. 18] The vision of a digital system, as set out in this document, presents a first approach to the essential components of software or database programming. [Fig. 19-20]

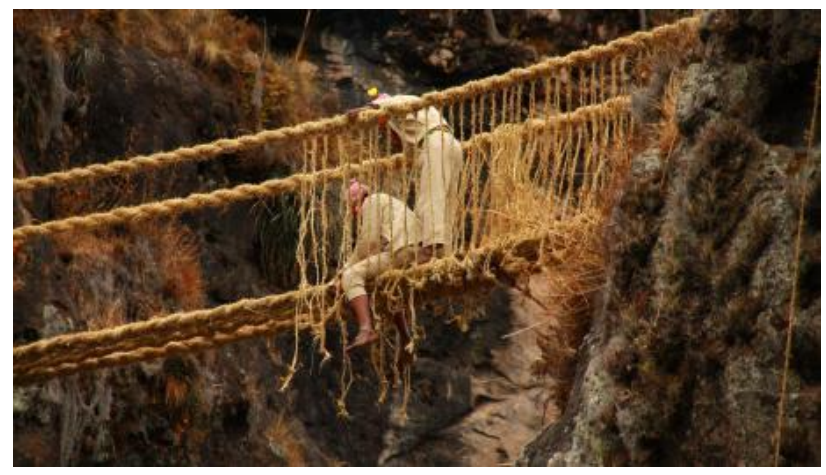

Figure 18. View of the Inca Bridge of Qeswachaca - Peru. () Knowledge and rituals associated with the annual renovation of the Q'eswachaka bridge are declared Intangible Cultural Heritage of Humanity. Ministerio de Cultura, Gobierno de Perú.

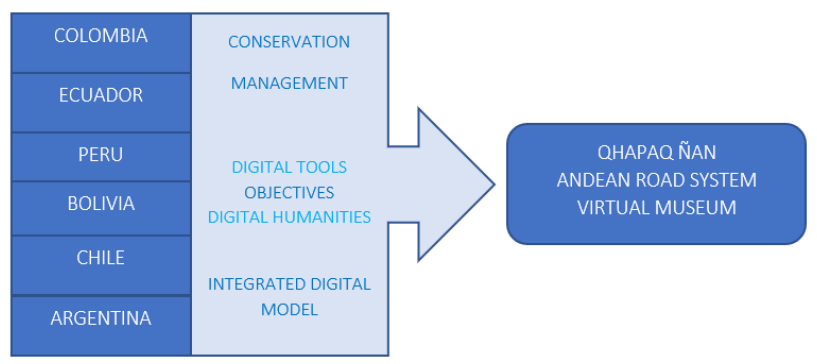

Figure 19. Graphic of Digital Information System for the Qhapaq Nan Andean Road System [Point 3.4.5].

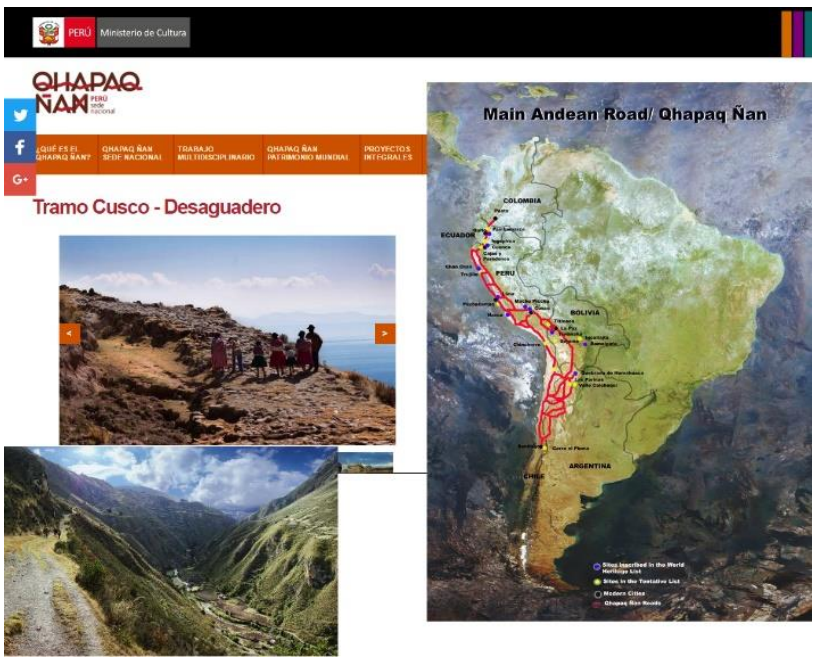

Figure 20. Sections, cultural landscape and map of the Andean Road System. . ( ) Project Qhapaq Nan - Sede Nacional, 2017. Ministerio de Cultura, Gobierno de Perú. UNESCO World Heritage Centre.

The contribution of this resource can be applied within the framework of cultural policies: especifically in the design of a Virtual Museum of Qhapaq Nan, managed by the six countries that share the itinerary of the Andean Road System, taking into account the following guidelines:

1- The Scientific Council adopted its interdisciplinary work topics for 2016 (Reconstructions), 2018 (Sustainability: Cultural Heritage and Sustainable Development) and 2019 (Territory: The World Rural Landscapes Iniciative) (ICOMOS, 2015). 
2- Cultural Landscape is one of the strongest determinants of the 'Sense of Place', yet it constitutes a largely unexplored realm when it comes to land-use planning. Landscape is a living entity and represents a cultural continuum. Change is inevitable and manifests itself as 'layers' over cultural Landscape. However, in this change from the traditional to the contemporary, one needs to assess those few and uncluttered principles that governed the intangible meanings of the space resulting in its uniqueness (Mohindru, 2011).

3- A virtual museum therefore, is based a piriori on this definition by association, and can be described as a digital entity that draws on the characteristics of the museum, in order to complement, enhance, or augment the museum experience through personalization, interactivity and richness of content. VMs can perform both as the digital footprint of a physical museum, or can act independently, while maintaining the authoritative status as bestowed by ICOM in its definition of a museum (Hazan and Hermon, 2015). [Fig. 21]
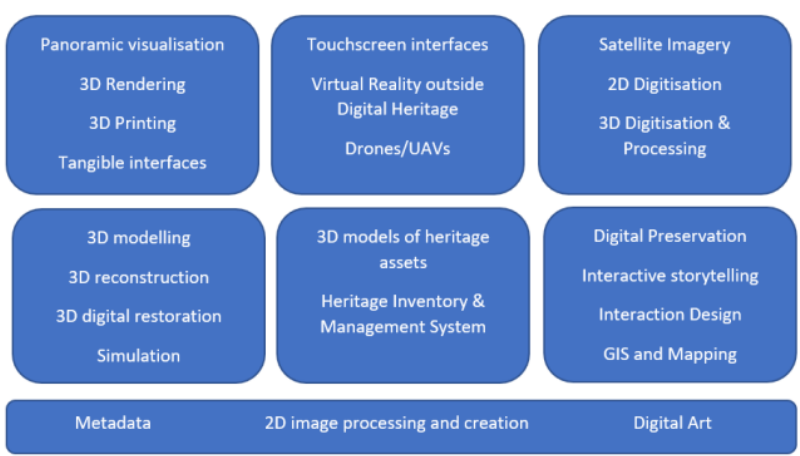

Digital Art

Figure 21. Graphic of components: Virtual Museum Projects. Deliverable Report. D 8.9 European Virtual Museum Observatory.

4- Cultural heritage, as expressed in the UNESCO [...] dictates that communities need to convey a testimony of their lived life, should be able to transmit their creative expressions, while securing the traces of their history for future generations. Cultural heritage therefore can be described as a bridge, or twoway process, paving the pathways that connect the past, to the present and to the future (Hazan and Hermon, 2015).

The concepts proposed, open a great panorama of action for the Project of a Virtual Museum for the Andean Road System. The difficulty and the challenge are presented in the joint work of the Latin American countries, due to differences in management policies, mainly. We propose in this case, an excellent guide: "Virtual Museum Principles" (vision for the future) for the protection and enhancement of the Andean Main Way:

1) The VM imbues the qualities of a museum through adhering to professional scientific inquiry; 2) The electronic actor performs throughout the sector with the same integrity as commanded by the physical museum; 3) Welcomes experts, curators, archaeologists, architects, engineers, artists, ethnographers, and other specialists in the field including computer experts and photographic specialists; 4) Acts to disseminate $\mathrm{VM}$ as sustainable, non profit entities acting on behalf of society. (This does not prohibit the VM from charging access to platforms in much the same way as Museums do with entrance tickets); 5) Adheres to best practice of digital methods and techniques in museums research, conservation and dissemination; 6) Maintains a distinctly identifiable ontological classification (comparable to the different kinds of physical museums) as historical, art, ethnographic, heritage center, encyclopedic, maritime, national, local, VM etc. ; 7) Adherence to ISO and similar internationally agreed upon standards; and 8) Contributes to the universalization of cultural heritage and open access for all (Hazan and Hermon, 2015).

\section{ACKNOWLEDGEMENTS}

Mario Santana Quintero, Stephen Fai and Christian Ouimet: Organizers of the 26th biennial CIPA symposium from August 28 to September 1, 2017. Committee on Monuments and Sites (ICOMOS). Carleton University, Ottawa, CIPA 2017.

Ministerio de Cultura. Gobierno del Perú. Colegio de México (Colmex). Universidad Nacional Autónoma de México (UNAM). Red de Humanidades Digitales (RedHD).

The Getty Conservation Institute and World Monuments Fund. Arches Project.

v-must . Virtual Museum Transnational Network.

\section{REFERENCES}

Arches Project. The Getty Conservation Institute and World Monuments Fund, 2017. Arches Demo. http://demo.archesproject.org/-Report.html (4 Jan. 2017).

Bouysse-Cassagne, T., Harris, O., Platt, T. y Cereceda, V., 1987. Tres Reflexiones sobre el Pensamiento Andino. Hisbol, La Paz, Bolivia, p. 44.

Cátedra UNESCO de Turismo Cultural Untref - Aamnba, con el apoyo de la Fundación Grupo El Abra (Salta), 2016. Jornada: Protección, conservación y gestión del QHAPAQ ÑN, Patrimonio Mundial, en el Alto Valle Calchaquí. Buenos Aires, Argentina.

http://www.turismoculturalun.org.ar/activ_2016_qhapaq.php Report.html (2 Jan. 2017).

CMN. (Consejo de Monumentos Nacionales) Gobierno de Chile, 2016. Qhapaq Ñan - Sistema Vial Andino. Chile. http://www.monumentos.cl/consejo/606/w3-propertyvalue41894.html-Report.html (2 Jan. 2017).

CONACYT, 2017. Tecnologías digitales para la difusión del patrimonio cultural 4 http://newsnet.conacytprensa.mx/index.php/fotostock/mediaite $\mathrm{m} / 10047$-tecnologi-as-digitales-para-la-difusio-n-delpatrimonio-cultural-4-Report.html (4 Jan. 2017).

D’Altroy, T., 2003. Los Incas. Ariel Pueblos, Barcelona, p. 195.

Google Earth, 2017. US Dept. of State Geographer. Search results: Historic Sanctuary of Machu Picchu. Peru; Geographic situation of the Andean Road System; the Inca Bridge of Qeswachaca. https://www.google.com/earth/ -Report.html (4 Jan. 2017)

González Díaz, S., Aguilar Hidalgo, J., y Garrido Escobar, F., 2015. El Sistema Vial Andino y los Incas en el Norte de Chile. Alvimpress Impresores LTDA. Consejo de Monumentos Nacionales Programa Qhapaq Ñan, Chile. http://www.monumentos.cl/consejo/606/articles55450_doc_pdf.pdf-Report.html (4 Jan. 2017), p. 16.

Hazan, S., Hermon, S., 2015. Deliverable Report. D 3.2, European, sustainable virtual museum. v-must . Virtual Museum Transnational Network. Cyprus Institute. http://www.v-must.net/library/documents/d32-european- 
sustainable-virtual-museum-Report.html (4 May 2017), pp. 1013 .

ICOMOS, 2015. ICOMOS Annual Report 2015. http://www.icomos.org/en/about-icomos/mission-andvision/icomos-mission/annual-report/7651-icomos-annualreport-2015-now-available-Report.html (3 May 2017), p. 23.

Instituto Geográfico Nacional, 2016. Base de Datos Geográfica. Visor SIG. República Argentina. http://sig.se.gob.ar/visor/visorsig.php-Report.html (3 Jan. 2017).

Instituto Nacional de Antropología y Pensamiento Latinoamericano, 2015. Qhapaq Ñan-Sistema Vial Andino. Argentina. https://inapl.cultura.gob.ar/noticia/qhapaq-nansistema-vial-andino/-Report.html (4 Jan. 2017).

Ministerio de Cultura. Gobierno del Perú. QHAPAQ ÑAN PERÚ Sede Nacional, 2015. Declaratoria del Qhapaq Ñan como Patrimonio Mundial. Lima, Perú. http://qhapaqnan.cultura.pe/procesoydeclaratoria/declaratoriaReport.html (4 Jan. 2017).

Ministerio de Cultura. Gobierno del Perú, 2016. ¿Qiénes somos? Lima, Perú. http://www.cultura.gob.pe/es/informacioninstitucional/quieness omos-Report.html (4 Jan. 2017).

Ministerio de Cultura. Gobierno del Perú, 2015. Proyecto de Tramo Huánuco Pampa - Huamachuco. Lima, Perú. http://qhapaqnan.cultura.pe/content/proyecto-de-tramo-

hu\%C3\%A1 nuco-pampa-huamachuco-Report.html (5 Jan. 2017).

Mohindru, S., 2002. Cultural landscapes in contemporary planning framework. 13th ICOMOS General Assembly and Scientific Symposium, Madrid. http://www.icomos.org/madrid2002/actas/45.pdf-Report.html (3 May 2017), p. 23.

Oficina de la UNESCO en Santiago, 2016. Informe sobre Industrias creativas. Chile. http://www.unesco.org/new/es/santiago/culture/creativeindustries/-Report.html (20 Oct. 2016).

Pletinckx,D., Capurro, C., Ferdani, D., and Pescarin, S., 2015. Deliverable Report. D 8.9, European Virtual Museum Observatory. v-must . Virtual Museum Transnational Network. CNR, Fraunhofer. http://www.vmust.net/library/documents/d89-eu-virtual-museumobservatory-evmo-Report.html (4 May 2017), pp. 2-4.

Porcayo Gatica, G., 2016. Digitalizando las Humanidades. Consejo Nacional de Ciencia y Tecnología CONACYT. México.

http://www.conacytprensa.mx/index.php/ciencia/humanidades/6 875-digitalizando-humanidades-Report.html (3 Jan. 2017).

Porcayo Gatica, G., 2016. Tecnologías digitales para la difusión del patrimonio cultural: RedTDPC y su vinculación con el INAH. Consejo Nacional de Ciencia y Tecnología CONACYT.

México. http://www.conacytprensa.mx/index.php/ciencia/humanidades/8 609-tecnologias-digitales-para-la-difusion-del-patrimoniocultural-Report.html (4 Jan. 2017).

Rolandi, D. Caraballo, C., Marcone Flores, G., Lazarovich, M. y Sosa, V., 2015. Jornada: Protección, conservación y gestión del Qhapaq Ñan, Patrimonio de la Humanidad. Cátedra
UNESCO de Turismo Cultural Untref - Aamnba. Buenos Aires, Argentina.

http://www.turismoculturalun.org.ar/activ_2015_proteccion_sist ema_vial_andino.php-Report.html (4. Jan. 2017).

Russell, G., 2011. ¿Qué son las Humanidades Digitales? Revista Digital Universitaria 1 de julio 2011. Volumen 12 Número 7. ISSN: 1067-6079. Coordinación de Acervos Digitales. Dirección General de Cómputo y de Tecnologías de Información y Comunicación - UNAM. México. http://www.revista.unam.mx/vol.12/num7/art68/art68.pdfReport.html (2 Jan. 2017).

Télam - Agencia Nacional de Noticias, 2016. Siete provincias debaten el plan de gestión para el Camino del Inca o Qhapaq Nan. CABA, Argentina. http://www.telam.com.ar/notas/201611/171207-sieteprovincias-debaten-el-plan-de-gestion-para-el-camino-del-incao-qhapaq-nan.html-Report.html (2 Jan. 2017)

Tecnología e Informática Grado 9, 2012. Componentes de Software.

https://sites.google.com/site/presentacioncartagoti09/component es-de-software-Report.html (2 Jan. 2017).

Turismo del desierto de Atacama, 2015. Routes of the Qhapaq Nan, Chile. http://caminodelincachile.cl/-Report.html (4 Jan. 2017).

UNESCO, 2014. ¿Qué es la UNESCO? http://www.unesco.org/new/es/unesco/about-us/who-weare/introducing-unesco/-Report.html (20 Oct.2016).

UNESCO, 2014. Servicio de Prensa. Oficina de UNESCO en Quito. UNESCO incluye el QHAPAQ ÑAN, Sistema Vial Andino, en la Lista de Patrimonio Mundial. Quito, Ecuador. $\mathrm{http} / / / \mathrm{www}$.unesco.org/new/es/media-services/single-

view/news/unesco_incluye_el_qhapaq_nan_sistema_vial_andin o_en_la_li/-Report.html (3 Jan. 2017).

Vileikis, O., Santana Quintero, M., Van Balen, K., Dumont, B., Tigny, V., 2011. XXIIIrd International CIPA Symposium Information Management Systems for Cultural Heritage and Conservation of World Heritage Sites. The Silk Roads Case Study, Prague, Czech Republic, organized by CIPA, ISPRS and CTU in Prague with special ICOMOS section. https://ojs.cvut.cz/ojs/index.php/gi/article/view/gi.6.45/2536Report.html (3May 2017), p. 366.

World Heritage Centre, 2012. Main Andean Road - Qhapaq Ñan. París, France. http://whc.unesco.org/en/activities/65/Report.html (4 Jan. 2017). 